\title{
Kula UNESCO Global Jeoparkı'nda Yerbilimleri ve Jeomiras Açısından Uluslararası Öneme Sahip Üç Yeni Jeosit Önerisi
}

\author{
Recommendation of Three New Geosites that are Internationally Significant in \\ Terms of Geo-Heritage within the Territory of the Kula UNESCO Global Geopark
}

\begin{abstract}
Ahmet Serdar AYTAÇ * Tuncer DEMIR **

Öz: Yer tarihine tanıklık etmiş, yerin jeolojik - jeomorfolojik evriminin kayıt ve kanıtlarını barındıran jeoparklar, söz konusu doğal değerlerin korunup gelecek kuşaklara aktarılmasında büyük öneme sahiplerdir. Jeoparklar bu özelliklerinin yanında bulun dukları alanda yöre halkının sosyo-ekonomik kültürel kalkınmasını hedeflemeleri nedeniyle sürdürülebilir kalkınma alanı ve enstrümanı konumundadırlar. Kula Jeopark1, Paleozoik yaşlı metamorfik kayaçlardan (şist, gnays) prehistorik volkanik püskürmelere kadar yer kürenin yaklaşık 200 milyon yıldan fazla jeolojik geçmişinin delillerini barındırır ve bu yönüyle oldukça zengin bir jeoçeşitliliğe (geodiversity) ev sahipliği yapar. Kula Jeoparkı Türkiye'nin en genç volkanik alanlarından biri ve aynı zamanda Türkiye'nin ve Türk Cumhuriyetleri'nin UNESCO etiketli ilk ve tek jeoparkıdır. Bu çalışmada, uzun yıllardan beri Kula Yöresi dâhilinde uluslararası bir ekiple sürdürdüğümüz jeomorfolojik araştırmalardan elde ettiğimiz bulgular işığında, Kula UNESCO Global Jeoparkı'nda jeosit olarak belirlenip tescillenmesi gereken, yerbilimleri ve jeomiras açısından uluslararası öneme sahip üç yeni alan (potansiyel Jeosit) önerilip buraların yerbilimleri ve jeomiras açısından önemlerinin ortaya konulması amaçlanmıştır. Bu açıdan bu çalışmanın Kula yöresinin yerbilimleri açısından ulusal ve uluslararası önemine yeni bir boyut ekleyeceği düşünülmektedir.
\end{abstract}

Anahtar sözcükler: Jeomiras, Jeosit, Jeopark, Kula UNESCO Global Jeopark1, Jeokoruma

Abstract: Geoparks, which are witnesses for the history of the earth and contain the record and evidence of the geological-geomorphological evolution of the earth, are of great importance in preserving our natural heritage and transferring it to future generations. In addition to these characteristics, Geoparks are also instruments and areas of significant sustainable development since they aim for the socio-economic and cultural development of the local people. The Kula Geopark contains evidence from more than 200 million years of earth history, from Palaeozoic metamorphic rocks to prehistoric volcanic eruptions. With these characteristics, the Geopark area exhibits a very rich geological diversity. The Kula Geopark is one of the youngest volcanic regions of the Turkey, at the same time the Kula geopark is the first and only UNESCO recognised geopark in Turkey and Turkic Republics. In this study, from the new finds provided by geomorphological research carried out with an international team in Kula Region for many years, we propose three new areas that are internationally important in terms of geo-science and geo-heritage, which should be registered as being internationally significant geo-sites by the UNESCO Global Geopark. In this respect, it is expected that this study will contribute a new dimension to the national and international value of the geology and geomorphology of the Kula region.

Keywords: Geo-Heritage, Geosite, Geopark, Kula UNESCO Global Geopark, Geo-Protection

* $\quad$ Dr. Öğr. Üyesi, Harran Üniversitesi, Fen-Edebiyat Fakültesi, Coğrafya Bölümü, Şanlıurfa. aserdaraytac@harran.edu.tr, https://orcid.org/0000-0001-8638-038X

** Prof. Dr., Akdeniz Üniversitesi, Edebiyat Fakültesi, Coğrafya Bölümü, Antalya. tuncerdemir@akdeniz.edu.tr, https://orcid.org/0000-0003-2740-7268 


\section{Giriş}

Ege Bölgesi’nde İç Batı Anadolu Platoları'nın hemen batısında yer alan Kula UNESCO Global Jeoparkı, Manisa İli sınırları içinde yer almakta olup, yaklaşık $930 \mathrm{~km}^{2}$ yüz ölçüme sahiptir (Şekil 1). Gerilme rejimli tektoniğin aktif olduğu bir bölgede bulunan Kula Jeopark1 ve çevresi jeolojik ve tektonik açıdan oldukça karmaşık, jeomorfolojik açıdan ise oldukça zengin yer şekillerine sahiptir. Jeoparkın da içerisinde bulunduğu yöre, Paleozoik yaşlı metamorfik kayaçlardan (şist, gnays) prehistorik volkanik püskürmelere kadar yerkürenin yaklaşı olarak 200 milyon yıldan daha uzun geçmişinin delillerini barındırmakta ve bu yönü ile oldukça zengin bir jeolojik çeşitliliğe (geodiversity) ev sahipliği yapmaktadır.

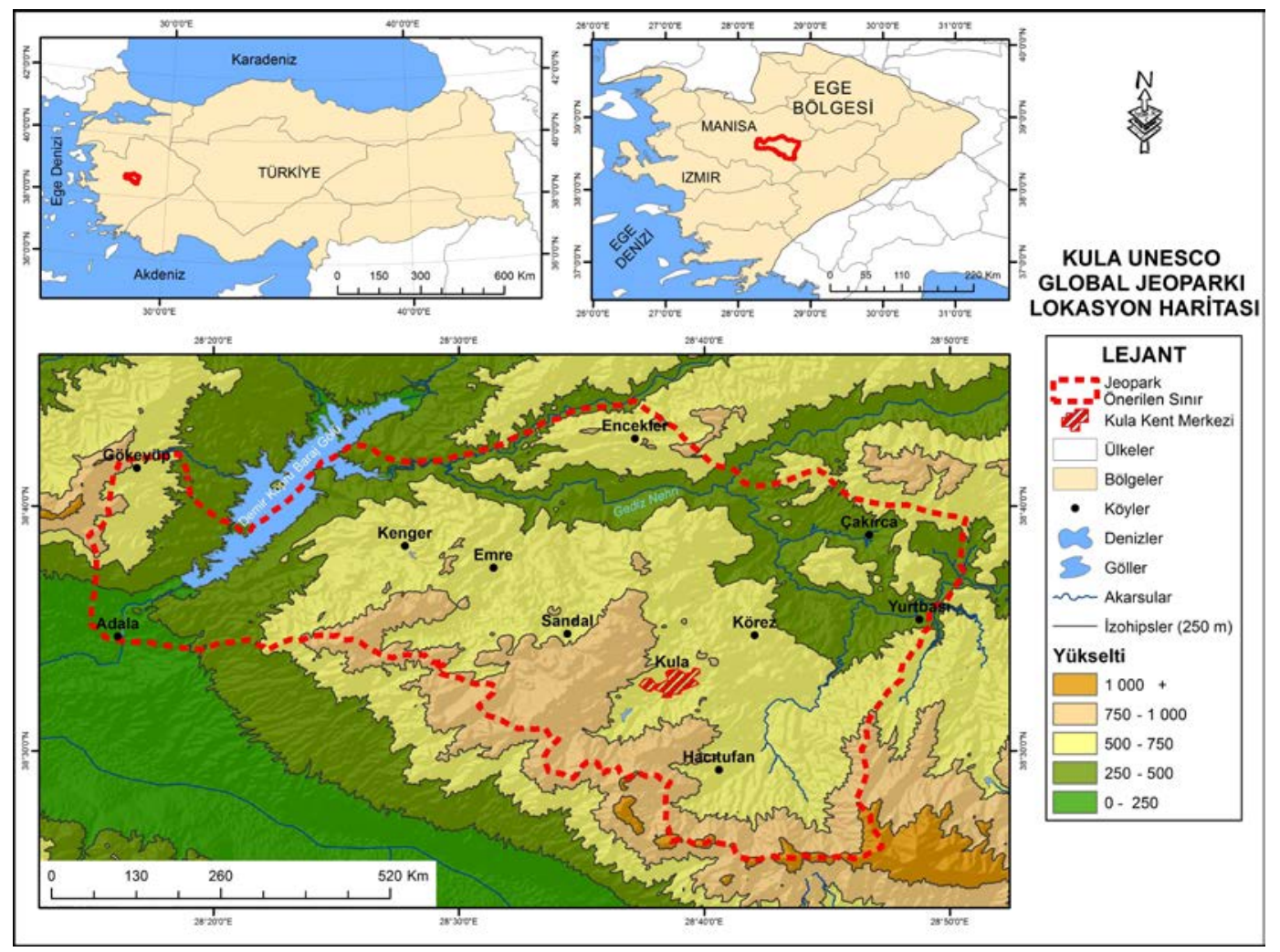

Fig. 1. Kula Jeoparkının lokasyon haritası

Kula Yöresi, doğa bilimleri ve özellikle yer bilimleri açısından araştırılması gereken dünyanın nadide alanlarından birisini oluşturmaktadır. Yörenin bu özelliği kazanmasının en önemli nedeni; geçirmiş olduğu jeomorfolojik ve jeolojik (tektonizma, iklim değişikliği ve volkanizma) evrim ve bu evrime ait kanıtların en eskisinden en yenisine kadar büyük çoğunluğunun günümüze kadar önemli ölçüde korunabilmiş olmasıdır. Her ne kadar, dünyanın değişik yörelerinde de benzer evrim geçirmiş alanlar bulunsa da bu sahalar geçirmiş oldukları evrimin kayıtlarını daha sonra etkili olan erozonal süreçlere bağlı olarak önemli ölçüde yitirmişlerdir. Kula yöresinde ise, geçmiş jeolojik dönemlerde etkili olmuş etken ve süreçlerin kayıtları, bölgede Erken Pleistosen'den itibaren aralıklı olarak meydana gelmiş volkanizma ve bununla ilgili bazaltik lav akıntıları ile örtülerek erozyonal süreçlerden minimum ölçüde etkilenmiş ve günümüze kadar korunabilmişlerdir.

Kula Yöresinin Jeopark ilan edilme sürecinin 10 yıllık bir geçmişi bulunmaktadır. 20072008 yıllarında $\mathrm{AB}$ hibe programları çerçevesinde alınan bir proje ile filli olarak başlatılan çalışmalar, 2012'de Türkiye'nin Avrupa Jeoparklar Ağı'na ilk resmi başvurusuyla devam etmiş ve Mart 2013'de ise Kula Volkanik sahası Türkiye'nin ilk global jeopark adayı olmuştur. 5 Eylül 
2013 tarihinde ise 12. Avrupa Jeoparklar Konferans1'nda Kula Volkanik Jeopark1 Kalite sertifikasını almış ve böylece Kula Jeoparkı Avrupa ve Global Jeoparklar Ağı üyesi olup, "Global Jeopark" olma unvanını kazanmıştır. Söz konusu üyelik ile Kula Jeoparkı, Avrupa'nın 58. Dünya'nın ise 99. Global Jeoparkı unvanını kazanmıș, 2015 yılında Global Jeoparklar Ağı'nın UNESCO çatısı altına girmesiyle de alan, aynı zamanda UNESCO'nun bir koruma alanına haline gelmiştir. Kula jeoparkı Türkiye'nin ve Türk Cumhuriyetlerinin ilk ve tek, Ortadoğu'nun ise 2. UNESCO tescilli jeoparkıdır. 2017 yılında UNESCO temsilcilerinin denetiminde sarı kartla değerlendirilen Jeoparkta hali hazırda UNESCO'nun belirlediği kriterlere uygun olarak yeni sınırlarının ve jeositlerin belirlenmesi/tescillenmesi, UNESCO deneticilerinin saptadıkları diğer eksikliklerin giderilmesi, jeoparkın konum ve durumunun yeniden gözden geçirilip iyileştirilmesine ilişkin çalışmalar devam etmektedir.

Kula yöresi ve bu kapsamda Kula jeoparkı sahası, gerek jeolojik gerekse de jeomorfolojik özelliklerinden dolayı oldukça eski dönemlerden beri değişik seyyahların ve bilim insanlarının ilgisini çekmiş, bu insanların eserlerine konu olmuştur. Nitekim Kula volkanlarını anlatan antikçağ coğrafyacı Strabon, Geographica adlı eserinde Kula'yı yanık ülke anlamına gelen 'Katakekaumene' olarak tarif etmiștir. Kula volkanik yöresinin ünü antikçağdan beri bilinmesine rağmen yöredeki volkanizma ve volkanik şekiller üzerine bilimsel anlamda yapılan ilk araştırmalar 19. yüzyılın ortalarında başlamıştır. 1841'de Hamilton ve Strickland'ın volkanizmanın özellikleri ve evrelerine ilișkin çalışmalarını, Tchiatchaff (Asie Mineure, 1869), Washington (1894; 1900) ve Philippson'un (1913) araştırmaları izlemiştir (Koçman, 2004). Bu dönemde alanda çalışmaları olan diğer araştırıcılar ise Keppel (1830), Texier (1862), Bresh ve Premerstein'dir (1891). Bu araştırmacılardan Washington, Kula volkanik bazaltlarını petrografik ve kimyasal yönden incelemiş ve "Kulait" olarak özel bir terimle literatüre geçmesini sağlamıştır (Erinç 1970). Daha sonra Erinç (1955), Ozansoy (1972) ve daha yakın yıllarda Yalçınlar (1986-1987), Ozaner (1992), Kayan (1992) gibi bazı Türk araştırmacılar da bu yöredeki volkanik relief üzerine birtakım araştırmalar yapmıştır. 19. yüzyılda başlayan ve günümüze kadar süren araştırmalar kapsamında daha ziyade yöredeki volkanik oluşumlar, onların sınıflandırılması, volkanizmanın flüvyal süreçlerin gelişimi üzerine olan etkileri v.b. hususlar araştırılmıştır. Özellikle son 20 yılda Kula volkanik yöresi uluslararası alanda yer ve doğa bilimciler tarafindan bilimsel araştırmaların yoğun olarak yapıldığı bir saha durumuna gelmiş ve bu araştırmaların sonuçları uluslararası bilimsel dergilerde yayınlanmıştır (Richardson-Bunbury 1992; 1996; Maddy et al. 2005; 2007; 2008; 2012; 2015; 2017; Veldkamp et al. 2015; Wouter et al. 2015; Şahiner et al. 2017; Şen et al. 2019; v.b). Yapılan bu araştırmalar daha ziyade Kuaterner volkanizmasının başlaması ile volkanizmanın yöredeki flüviyal süreçleri nasıl etkilediği veya flüviyal süreçlerin volkanizmadan nasıl etkilendiği, volkanizmanın Kuaterner süresince yöredeki jeomorfolojik gelişimde meydana getirdiği kesinti ve karışıklıkların neler olduğu, volkanizma, iklim değişiklikleri ve tektonizmanın birlikte etkilerinin yer şekillerinin gelişimine etkileri ve bunların delillerinin belirlenmesi gibi konular üzerine yoğunlaşmıştır.

Kula yöresinin antikçağdan günümüze yerli-yabancı seyyahların ve bilim insanlarının dikkatini çekmesi ve alana ilişkin çok sayıda uluslararası yayının yapılmış olması, yörenin yerbilimleri açısından bölgesel, ulusal ve global ölçekte sahip olduğu önemin en açık göstergesidir. UNESCO Global Jeoparklar Ağı'nın kriterlerine göre bir alanın global jeopark statüsü kazanabilmesi için o alanın en az bir adet uluslararası öneme sahip jeosit barındırması ve alanın yerbilimlerine ilişkin uluslararası önemini göstermesi açısından alan veya söz konusu sitlere ilişkin uluslararası yayınların var olması gerekmektedir. Nitekim Kula Jeoparkı'nın Global Jeoparklar Ağı'na 2012 yılında gerçekleştirilen ilk başvurusunda, Jeopark alanının önemli kısmını kapsayan volkanik şekiller, Strabon ve diğer araştırıcıların (Hamilton \& Strickland 1841; Texier 1862; Philippson 1913; Washington, Canet \& Jaoul 1946; Erinç 1970; Ercan \& Öztunal1 1982; Ozaner 1992; Bunbury 1992) çalışmalarına atfen uluslararası öneme sahip sit olarak tanımlanmıştır. 
Bu makale kapsamında, uzun yıllardan beri Kula Yöresi ve aynı zamanda Kula Jeopark1 sınırları dâhilinde sürdürdüğümüz çok çeşitli ülkelerden yerbilimcilerin katılımı ile interdisipliner özellikteki arazi çalışmalarına dayalı bulgularımız ışı̆̆ında öncelikle sahanın jeolojik, jeomorfolojik ve tektonik evrimi ana hatları ile açıklanmaya çalışılmış, daha sonra ise Kula UNESCO Global Jeoparkı'nda jeosit olarak belirlenip tescillenmesi gereken, yerbilimleri ve jeomiras açısından uluslararası öneme sahip üç yeni alan (potansiyel Jeosit) önerilip buraların yerbilimleri ve jeomiras açısından önemlerinin ortaya konulması amaçlanmıştır. Bu açıdan bu çalışmanın Kula yöresinin yerbilimleri açısından ulusal ve uluslararası önemine yeni bir boyut ekleyeceği düşünülmektedir.

\section{Sahanın Jeolojik ve Jeomorfolojik Evrimi}

Kula jeopark sahası, Selendi Havzası'nın güney kesimi ile Gediz Grabeni'nin orta bölümünü kapsamaktadır. Bu saha Batı Anadolu aktif gerilme tektonik rejiminin etkili olduğu alanda yer almaktadır (Sarica 2000; Bozkurt 2001), (Fig. 2).

Gediz Grabeni'ni kuzeyden sınırlandıran horst bloku üzerinde bulunan Selendi Havzası, bölgedeki kuzeydoğu-güneybatı doğrultuda uzanan Gördes, Demirci ve Uşak-Güre havzaları ile birlikte Erken Miyosen'de etkili olmuş tektonik hareketlere bağlı olarak oluşmuş ve takip eden dönemlerde de flüviyal-kolluviyal kökenli Neojen depolarıyla doldurulmuştur (Fig. 3).

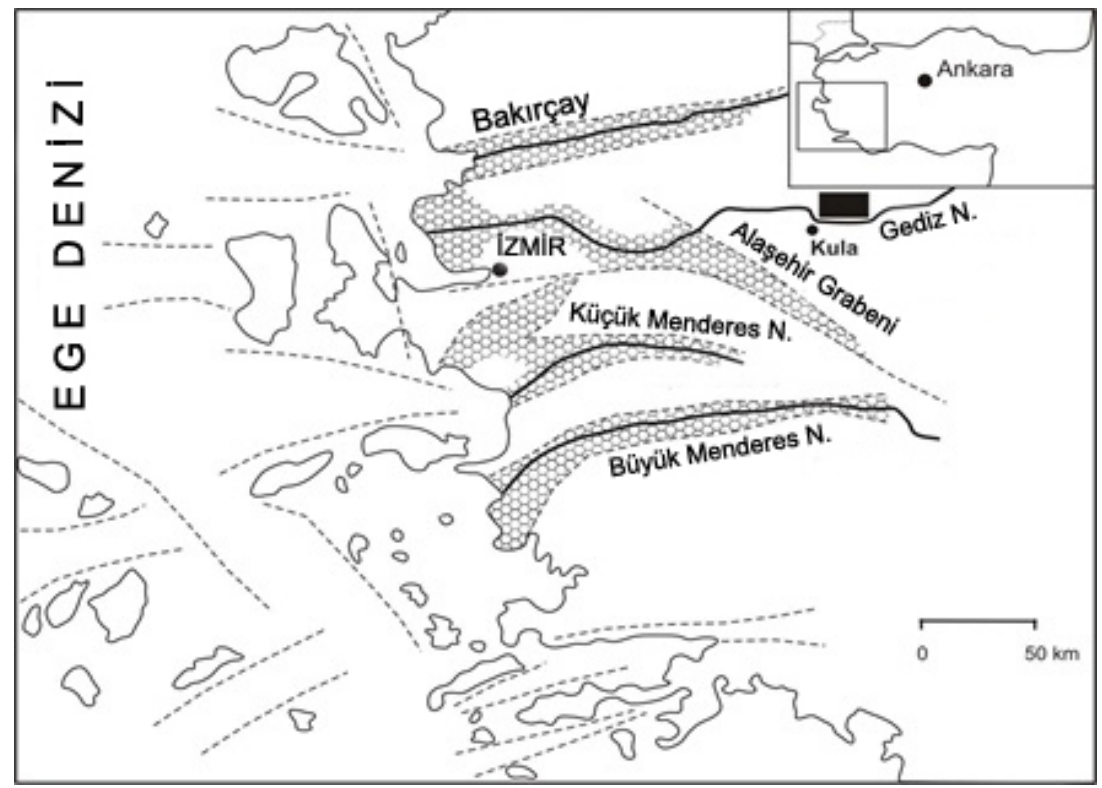

Fig. 2. Batı Anadolu'nun genelleştirilmiş tektonik yapıları (Aksu et al. 1987). (Taralı kısımlar Geç Senozoik graben sahalarını ve kesik çizgiler ise bölgedeki ana fayları göstermektedir)

Temelini genellikle metasediman ve ofiyolitik kayaçlardan oluşan Menderes masifinin oluşturduğu bu havzaların güney kesimleri sonradan meydana gelen ve kabaca doğu-batı doğrultusunda uzanan faylarla kesilmiştir. Bu havzaların oluşumları konusunda değişik görüşler ileri sürülmektedir. Seyitoğlu (1997)'na göre bu havzalar bölgede meydana gelen doğu-batı doğrultulu tektonik gerilimlerin ilk evrelerinde meydana gelen normal faylanmalar sunucunda oluşmuş grabenlerdir. İnci (2002) ye göre ise bu havzalar Post Alpin hareketler sonucu oluşan çökmeler (sübsidanslar) sonucunda oluşmuş olup, faylanmalarla herhangi bir ilgileri bulunmamaktadır. Purvis \& Robertson (2004)'in geliştirdikleri bir modele göre ise bu havzalar aslında kuzeygüney yönlü olan tektonik gerilimlerin ilk evrelerinde oluşmuşlardır ve bu gerilimler daha sonra Alaşehir ve Simav grabenlerinin oluşumuna sebep olmuşlardır (Şekil 3). 
Selendi havzasının litostratigrafik özellikleri değişik yerbilimcileri tarafından araştırılmıştır (Seyitoğlu 1997; Purvis \& Robertson 2004; Ersoy et al. 2010). Her ne kadar bu araştırmacılar havzadaki ana stratigrafik birimlerin özelikleri konusunda benzer tespitler yapmışlar ise de bu birimlerin yaşları konusunda farklı bulgular ortaya koymuşlardır.

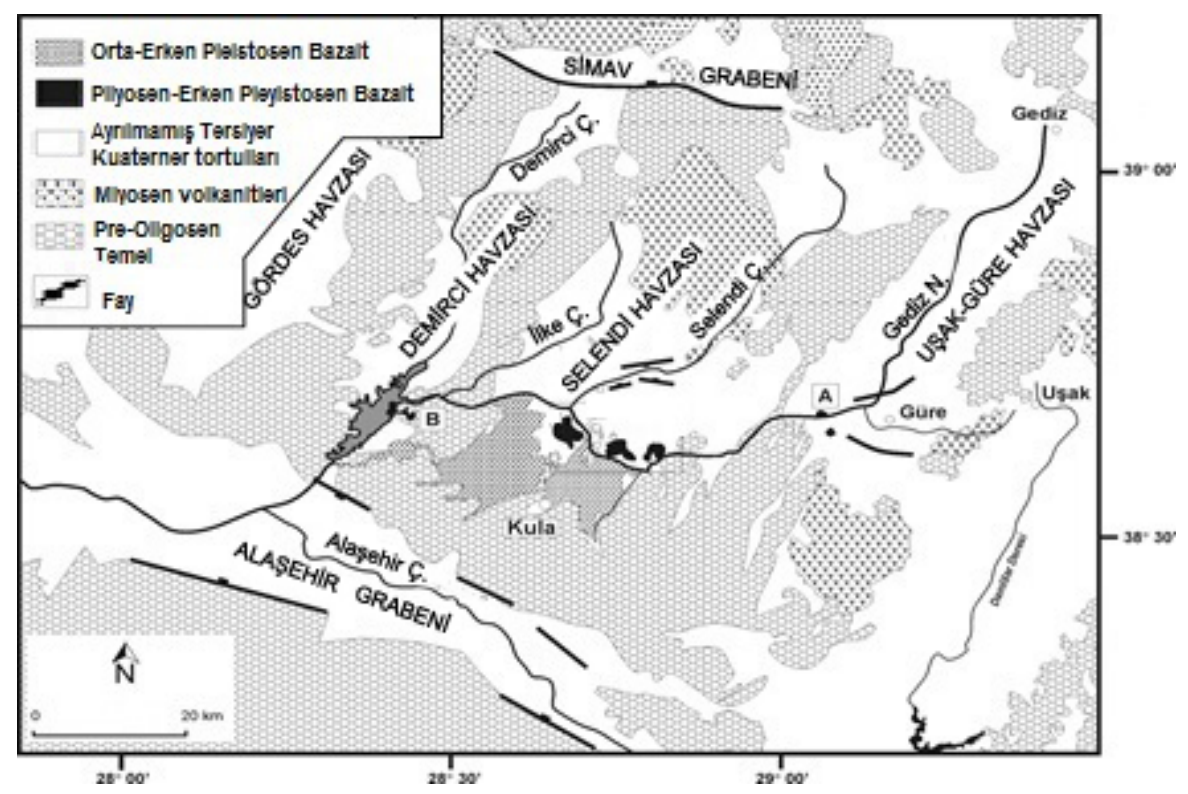

Fig. 3. Yukarı Gediz Havzası'nın ana jeolojik yapıları (Maddy et al. 2012)

Selendi havzasının temelini sahanın en yaşlı birimi olan Pre-Neojen (Palezoik) yaşlı genellikle gnays, şist, kuvarsit ve mermerlerden oluşan Menderes Masifi oluşturur. Menderes Masifine ait bu kayaçlar genellikle sahanın güney-doğusunda Neojen havza dolgularının erozyonla ortadan kaldırıldığı sahalarda yüzeylenmekte ve ayrıca yörede Gördes, Demirci, Selendi ve Uşak-Güre havzalarını birbirinden ayıran yüksek sahaları oluşturmaktadır. Menderes Masifi aynı zamanda sahada oldukça geniş alanlarda görülen Kratese yaşta ofiyolit ve ofiyolitik melanjların da altında bulunmaktadır. Selendi Havzasının en yaşlı dolgularını Hacıbekir Grubu olarak bilinen ve kalınlığı 400 m civarında olan konglomera depoları oluşturmaktadır (Şekil 4). Bunu İnay grubu olarak adlandırılan ve aşağıdan yukarıya doğru sırasıyla Ahmetler ve Ulubey formasyonları takip etmektedir (Seyitoğlu 1994, 1997). Ahmetler Formasyonu gri ve beyazıms1 fluviyal/kolluviyal kökenli detritik depolardan ibaret olup; bunun üzerinde Ulubey Formasyonu olarak adlandırılan gölsel ortamda oluşmuş karasal kökenli karbonatlardan oluşan kalker ve marnlar bulunmaktadır (Seyitoğlu 1997; Westaway et al. 2003; 2004; Purvis \& Robertson 2004; Ersoy et al. 2010).

Bölgede, gerek Geç Miyosenden itibaren hızlanan bölgesel tektonik yükselmeler ve gerekse de yörede NNE-SSW doğrultulu normal fayların oluşumunu başlatan gerilmeli tektonik rejimin başlaması, Selendi Havzası'nda gölsel sedimantasyonun sonlanmasını ve flüviyal süreçlere bağ11 aşınım olaylarının başlamasını tetiklemiştir (Bozkurt 2001; Bozkurt \& Sözbilir 2004; Ersoy \& Helvac1 2007; Maddy et al. 2017). Özellikle Pliosen-Kuvaterner döneminde meydana gelen kuzey-güney yönlü tektonik gerilimler, Kula yöresinin hemen güneyinde Alaşehir grabeninin de oluşumuna sebep olan yüksek açılı doğu-batı yönlü normal fayların meydana gelmesini sağlamıştır. Her ne kadar Alaşehir grabeninin oluşumuna sebep olan tektonik gerilimler Geç Pliosende (5 MY) başlamış ise de (Bozkurt \& Sözbilir 2004) grabeni sınırlandıran faylardaki hareketlenmelerin hızı yaklaşık olarak 1.6 MY önce artmış ve bu hareketlenmeler yörede Erken Pleistosen'deki ilk volkanizmayı tetiklemiştir (Bunbury et al. 2001). 


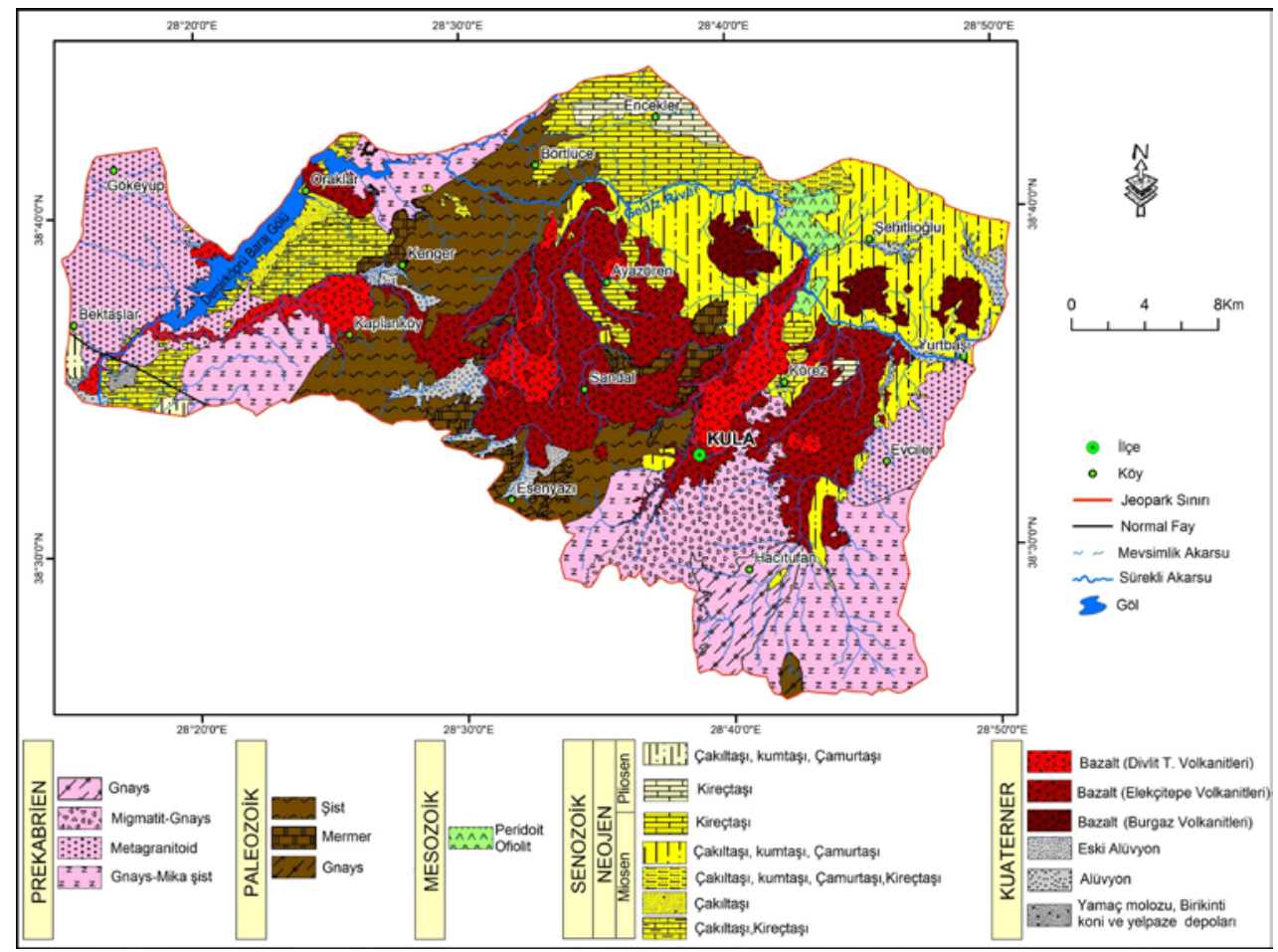

Fig. 4. İnceleme alanının jeoloji haritası

Yukarıda belirtilen bütün bu gerilme rejimli tektonik hareketler ve bunlara bağlı olarak oluşan kabaca doğu-batı yönlü normal faylar, yörede hem flüviyal drenaj sisteminin kurulmasında ve hem de bu sistemin doğrultularının belirlenmesinde önemli tektonik yapılar olarak rol oynamışlardır (Maddy et al. 2017; 2018). Böylece Paleo-Gediz ve kolları, başlangıçta Selendi Havzası'nı dolduran depoların en üst birimini oluşturan karasal kökenli karbonatlardan (kalker) oluşan Ulubey formasyonu üzerine kurularak yataklarını derinleştirmişlerdir. Bu depoların zamanla geniş bir şekilde erozyonla ortadan kaldırıldığı sahalarda ise Paleo-Gediz ve kolları daha aşağıda yer alan Ahmetler formasyonu üzerine intikal ederek bu havzanın dış drenaja bağlanmasına sebep olmuştur. Gölsel ortamda oluşmuş kalker ve marn depoları (Ulubey Formasyonu) üzerine kurulan Paleo-Gediz ve kolları, başlangıçta dar ve derin vadiler oluşturmuşlardır. Ancak bu depoların aşınımla ortadan kaldırıldığı sahalarda, daha aşağıda bulunan fluviyal-kolluviyal depolardan oluşan ve zayıf konsolide olmuş Ahmetler Formasyonu üzerinde daha geniş yataklar oluşturmuşlardır (Maddy et al. 2017; 2018).

Erken Pleistosen'den itibaren küresel ölçekte meydana gelen iklim salınımlarından (Milankoviç iklim salınımları) yöredeki flüviyal süreçler de etkilenmiş ve bunların sonucu olarak Paleo-Gediz birtakım taraçalar oluşturmuştur. Bu taraçalar bugün için yöredeki bazaltik lav akıntıları ile kaplı Sarnıç ve Burgaz platoları altında çok iyi muhafaza edilmiş durumdadırlar. Buna karşı1ık, sahada Erken Pleistosen bazaltik lav akıntıları tarafından korunmayan gevşek dokudaki Miyosen yaşta kolluviyal-flüviyal kökenli havza dolguları ise Gediz nehri ve kolları tarafından önemli ölçüde aşındırılmış ve bu depolar üzerinde tipik kırgıbayır (badlands) topografya örnekleri gelişme göstermiştir. Günümüzde Miyosen yaşta flüviyal kökenli havza dolgularının bütünü ile ortadan kaldırıldığı sahalarda ise temel arazi olan Menderes Masifini oluşturan kayaçlar yüzeylenmektedir (Maddy et al. 2005; 2007; 2012; 2017; Veldkamp et al. 2015).

Türkiye'nin en genç volkanik sahalarından birisi olan Kula Yöresinde, volkanizma Orta Miyosen'de başlamış ve değişik evrelerde olmak üzere 2.6 bin yıl öncesine kadar devam etmiştir (Westaway et al. 2003; 2004; Maddy et al. 2012; Wouter 2013; 2016). Yöredeki volkanik 
püskürme merkezleri ve bunlarla ilgili volkanik püskürme ürünlerinin yaşları, Selendi havzasında kuzeyden-güneye, Alaşehir grabeni'ne yaklaştıkça gençleşmektedir. Yöredeki en yaşlı volkanizma Orta Miosen'de meydana gelmiş olup, 14-16 milyon yıl önce gerçekleşmiştir (Bunbury et al. 2001; Purvis \& Robertson 2004; Maddy et al. 2017). Söz konusu volkanik aktivite bölgede etkili olan sıkışmalı tektonik rejime bağlı olarak meydana gelmiş olup, bu dönemde stratovolkan tipi volkanlar oluşmuştur. Söz konusu volkanlar, bölgedeki kuzeydoğu-güneybatı doğrultulu Gördes, Demirci ve Uşak-Güre havzalarında yer almakta ve bu havzaların en yüksek yer șekillerini olușturmaktadır. Yaygın püskürme ürünlerini riyolitik lav, kül, tüf ve diğer pirokalstik unsurlar meydana getirir. Bu volkanizmaya ait kül, tüf ve diğer piroklastik unsurlar Selendi Havzası'na Miosen süresince biriken flüvyal-kolluviyal kökenli dolgular arasında volkanoklastik tabakalar șeklinde ardalanmalı olarak yer almaktadır (Seyitoğlu 1997; Westaway et al. 2003, 2004; Purvis \& Robertson 2004).

Kula yöresinde Kuvaterner volkanizması günümüzden yaklaşık olarak 2 milyon yıl öncesinde başlamıştır (Richardson-Bunbury 1996). Bu volkanizma, Batı Anadolu'da Pliosen'de başlamış ve hâlihazırda da devam etmekte olan gerilme tektoniğine bağlı olarak meydana gelmiştir. Belirtilen volkanizmanın, muhtemelen bölgede Alașehir grabeninin de oluşumuna sebep olan riftlenmeler (gerilimler) ile ilgili olduğu ileri sürülmektedir (Ercan et al. 1983; Ercan 1993) (Şekil 1). Bu volkanların yaygın püskürme ürünlerini ise daha çok alkali türde bazaltik lav akıntıları, tefra ve cüruf gibi proklastik maddeler olușturur. Anadolu'da volkan topografyasının en genç örneklerinden birini oluşturan Kula volkanik sahasında bazaltik lav akıntıları ve piroklastik koniler, volkanik reliefin en yaygın şekillerini oluşturur. Yöredeki volkan konilerinin belirli hatlar boyunca sıralanmaları, sahadaki faylanmalarla doğrudan ilişkili olduklarına işaret etmektedir. Konilerin bir kısmı yalnızca piroklastik malzeme, bazıları da lav akıntılı piroklastik koniler şeklindedirler. Yörede, bu piroklastik konilerin en yenilerine "Divlit" veya "Devlit" adı verilmektedir.

Kula volkanlarından özellikle Kuaterner süresince meydana gelen volkanik faaliyetlerle ilgili olarak çıkan lavların genellikle alkali bazalt özelliğinde olduğu ve 68 volkan konisinden çıktığı belirtilmektedir (Erinç 1970). Bu kadar sayıca fazla volkan konisi olmasına rağmen, konilerin yükseltileri oldukça az (200-300 m'ler arası) çıkan lav ve proklastik madde ürünlerinin hacimleri de genelde azdır (2.3 km²) (Richardson-Bunbury 1996). Yörede, Erken Pleistosen dönemine ait en eski volkan 1.6 milyon yaşında olup Kula'nın yaklaşık olarak 20 km batısında bugünkü Demirköprü baraj gölü kıyısında bulunmaktadır. Yörede volkanizma 2.6 bin yıl öncesine kadar devam etmiş, volkanizmanın son etkinliğine burada yaşamış olan prehistorik insanlar da tanıklık etmiş ve nihayet tüfler üzerinde bu insanların ayak izlerine rastlanmıştır.

\section{Bulgular}

Kula Yöresinde uzun y1llardan beri sürdürmekte olduğumuz araştırmalar kapsamında, Kula Jeopark1 sınırları dâhilinde küresel iklim değişikliği, paleo çevre koşulları, geçmiş dönemlerde meydana gelen doğal afetler ve volkanizma ile ilişkili yer tarihi ve İnsanlık tarihinin delilleri mahiyetinde, yerbilimleri ve jeomiras açısından öneme sahip üç yeni jeosit olması gereken alan belirlenmiştir. Jeosit olması önerilen alanlar, küresel iklim değişikliği ve insanlık tarihini açısından öneme sahip olmaları ve yer tarihinin önemli delillerini barındırmaları nedeniyle uluslararası öneme sahiplerdir. Söz konusu alanlara ilişkin uluslararası düzeyde yayınlardan giriş kısmında söz edildiği gibi bu araştırmalardan bazılarına bu çalışmanın kaynakçasında da yer verilmiştir. Bu alanların jeosit olarak tescillenip korunması yer ve insanlık tarihine ilişkin delillerin muhafaza edilmesi açısından son derece önemlidir. Söz konusu alanların genel özellikleri ve jeomiras açısından önemlerine aşağıda kısaca yer verilmiştir. 


\section{Erken Pleistosen Paleo-Gediz Taraçaları}

Kula Jeopark sınırları dâhilinde Erken Pleistosen dönemi bazaltik lav akıntıları ile örtülü Burgaz, Sarnıç ve kısmen de İbrahimağa platoları altında Paleo-Gediz nehrine ait flüviyal depolar tespit edilmiştir (Maddy et al. 2005; 2012; 2017). Bu depolar, özellikle Burgaz Platosu çevresinde, Miyosen yaştaki flüviyal-kolluviyal özellikteki havza dolguları (Ahmetler Formasyonu) üzerinde ve Erken Pleistosen yaştaki lav akıntıları altında yer almakta ve bu platoların kenarlarında birçok lokasyonda mostra vermektedirler. Sahada yapılan ayrıntılı seviye ölçümlerinden elde edilen sonuçlara göre, yükseltileri platoların kuzeyinden güneyine doğru düzenli olarak azalmakta olan bu Paleo-Gediz sedimanları aslında kabaca doğu-batı doğrultusunda uzanan 11 taraça seviyesini oluşturmaktadır (Maddy et al. 2015-2017). Bu taraçaların 5 tanesi (T11 -T7) Erken Pleistosen volkanizması öncesi (1.64 - 1.33 my aras1), 6 tanesi ise (T6 - T1) volkanizma başladıktan sonra meydana gelmiştir (Maddy et al. 2017).

Burgaz ve Sarnıç platoları üzerinde taraçaları örten bazaltik lav akıntılarının radyometrik (K-Ar) yaş tayinleri söz konusu taraçaların günümüzden 1.67-1.25 milyon yılları arasında dönemde oluştuklarını ortaya koymuştur. Bu taraçalardan ilk 5 tanesi (T11-T7) volkanizma öncesi, 6 tanesi ise (T6-T1) volkanik faaliyetlerin meydana geldiği dönemde oluşmuşlardır. Taraçaların oluşumunu sağlayan mekanizmalar ise; Alaşehir Grabenini kuzeyden sinırlandıran taban bloğunda meydana gelen göreceli yükselmeler, bölgesel düzeyde etkili olan tektonik yükselmeler ile Erken Pleistosen süresince yer ekseninde 41 biner yıllık periyodik değişmelerin sebep olduğu iklimdeki salınımlarının birlikte etkileri sonucunda olduğu belirtilmiştir (Maddy et al. 2005, 2007,
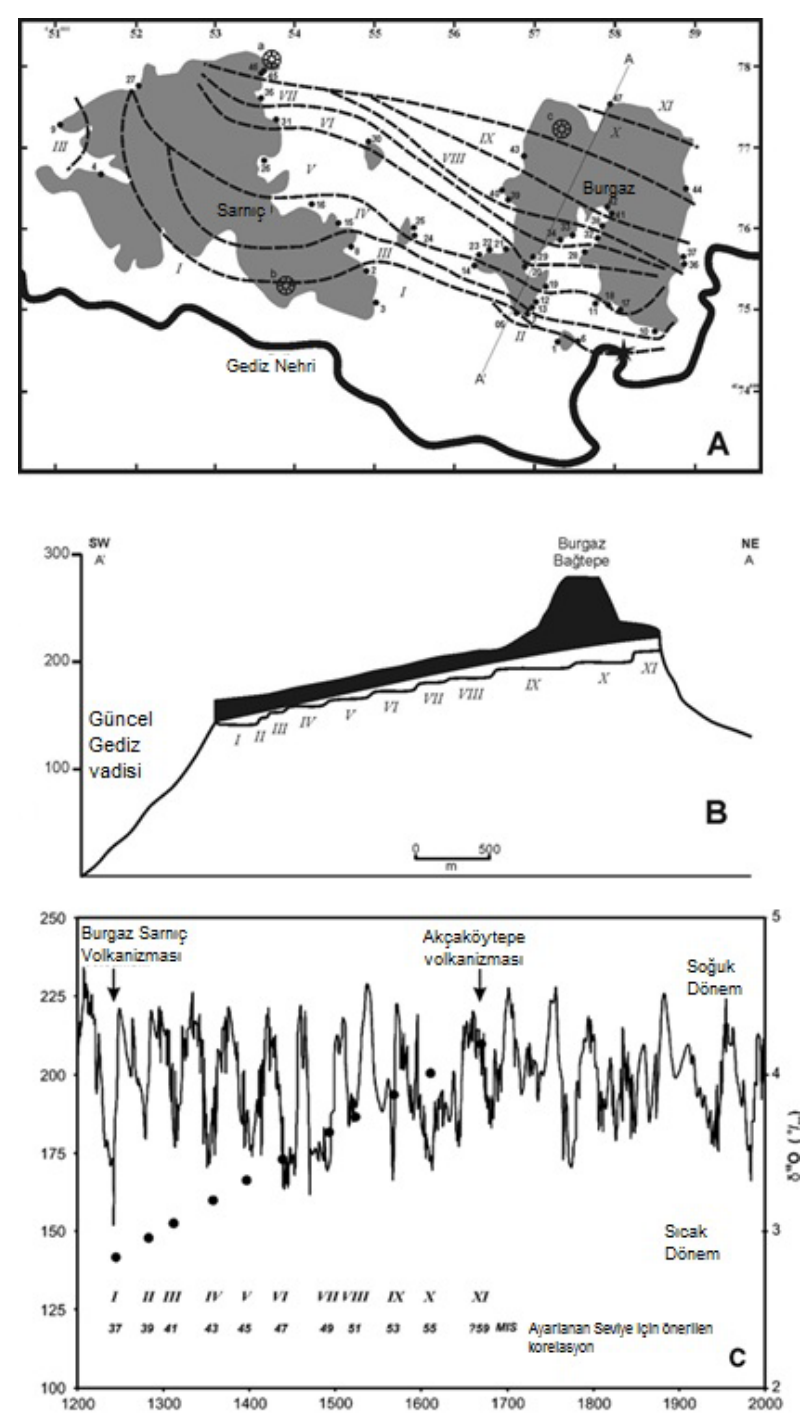

Fig. 5. (A) Lav akıntıları tarafindan örtülmüş Erken Pleistosene dönemine ait Gediz taraçalarını gösterir harita (Maddy et al. 2005). Lav akıntıları altındaki Gediz taraçalarının aflore (yüzeylenme) gösterdiği lokasyonların (1-47) rakamları şeklinde gösterilmiştir. 3 ana volkan konisi ise sırasıyla; a- Toytepe, b-Sarnıç Bağtepe ve c-Burgaz Bağtepe olarak işaretlenmiştir. (B) Burgaz Bağtepe volkanından çıkan lavların taraçalar ve aluviyal fan depolarını örttüğünü şematik olarak göstermektedir. (C) Denizel oksijen izotop evrelerinin (MIS) Erken Pleistosen dönemindeki değişimi. (Yayınlanmış yaşlandırma modelleri esas alınmıştır-Eastern Mediterranean Ocean Drilling Program-ODP967) (Kroon et al. 1998). Denizel izotop evreleri sadece buzul arası dönemler için numaralandırılmıştır. 2017).

Buna göre, soğuk-kurak dönemlerde akarsu akım miktarları azalmış ve bunun sonucunda akarsu yatağında daha sonraları taraçaları depolarını oluşturacak sedimanlar birikmiştir. Soğuk 
dönemlerden sıcak dönemlere geçişlerde artan nemliliğe bağlı olarak vadi yamaçlarında bitki örtüsü gürleşmiş, bu da yamaç stabilitesini artırmıș, kar erimeleri ve artan yağıș miktarlarına bağlı olarak ta akarsuyun akım miktarları artmıştır. Bunun sonucunda akarsu soğuk dönemde yatağında biriktirmiş olduğu sedimanlar içine gömülerek taraça oluşturmuştur. Kısacası, soğuk dönemlerde akarsu vadisinde sedimantasyon, soğuk-sıcak geçiş dönemlerinde ise derine kazma olayı gerçekleşmiş ve taraça basamakları oluşmuştur.

Kula yöresinde taraça oluşumlarına sebep olan iklim değişikliklerinin esasında Erken Pleistosen'de küresel ölçekte meydana gelen iklim salınımları ile büyük ölçüde uyumlu olduğu, Doğu Akdeniz'de sürdürülen Okyanus Sondaj Program-9678180 (Ocean Drilling ProgramODP-967 8180) kapsamında elde edilen Oksijen İzotop kayıtları (OIS) ile de doğrulanmıştır. Bu program kapsamında elde edilen sonuçlara göre, Erken Pleistosen süresince iklimde yüksek frekanslı ancak düşük amplütüdlü sıcak-soğuk salınımların yaşandığı ve bu salınımların ise 41 biner yıllık Milankovitch iklim döngüleri ile ilişkili olduğu ileri sürülmüştür (Kroon et al. 1998). Nitekim benzer şekilde Doğu Akdeniz de çevresel değişimlerin örnekleri Yunanistan'ın Tenaghi Philippon bölgesindeki vejatasyon kayıtlarının incelenmesi sonucunda da (polenle) açıkça ortaya konulmuştur. Böylece, Kula yöresinde Erken Pleistosen taraçalarının oluşumuna sebebiyet veren iklim değişmelerinin Doğu Akdeniz'de meydana gelmiş iklim değişimleri ile büyük bir paralellik gösterdiği gerçeği ortaya konulmuştur (Fig. 5).

Kula Yöresindeki Erken Pleistosen taraçaları, yer eksen eğikliğinde meydana gelen periyodik değişmelerin sebep olduğu bölgesel iklim değişiklikleri ile flüviyal sistemin bu değişikliklere gösterdiği tepkilerin kayıtlarını oldukça iyi bir şekilde içermesi bakımından küresel düzeyde oldukça önemlidir. Bu türde kayıtlar, diğer bir anlatımla bölgesel tektonik yükselme ve yüksek frekans ve düşük amplitüdlü iklim değişimlerine bağlı olarak oluşan flüviyal taraça oluşumları, dünyanın başka yerlerinde henüz tam olarak tespit edilememiştir. Bunun sebebi şu şekilde açıklanabilir; Her şeyden önce yörede taraça oluşumu için uygun tektonik yükselme koşullarının mevcut olması gerekir. Bu tektonik yükselmelerin hızı, ne akarsuyun yatağına biriktirdiği sedimanların içerisine gömülmesi ve dolayısı ile taraça basamağı oluşumunu zorlaştıracak şekilde yavaş olmalı ve ne de (özellikle soğuk dönemlerde) akarsu vadilerinde taraça dolgularının birikimini zorlaştıracak şekilde hızlı olmalıdır. Her ne kadar hızlı tektonik yükselmelerin olduğu sahalarda da flüviyal taraçalar oluşmakta ise de bu taraçalar hızlanan erozyona bağlı olarak sonradan kolayca tahrip olmaktadır (Maddy 1997).

Diğer önemli bir husus ise, yüksek frekans ve düşük amplitüdlü iklim değişiklerinin genellikle taraça oluşumları için uygun koșullar oluşturmaması durumudur (Maddy 1997). Nitekim bu türde iklim salınımları, Orta ve Geç Pleistosen süresince meydana gelen düşük frekans fakat yüksek amplitüdlü iklim salınımlarının aksine, sadece iklimde kısa süreli (41 bin yıl) soğuksıcak dönemlerin yaşanmasına sebep olmakta, bu durum da flüviyal süreçler üzerinde taraça oluşumları bakımından (birikim ve aşınım) çok bariz etkiler oluşturamamaktadır. Oysa Kula yöresinde, bazaltik lav akıntıları ile kaplı Burgaz ve Sarnıç platoları altında, Erken Pleistosende oluşmuş taraçalar, yüksek frekans ve düşük amplitüdlü iklim değişiklerine bağlı olarak meydana gelmiş taraça basamaklarının en güzel örneklerini yansıtmaktadırlar. Bu taraçalar, oluşumlarını müteakip dönemlerde flüviyal fan depoları ile örtülmüş, bunun akabinde ise söz konusu dönemde meydana gelen volkanik faaliyetlere bağlı olarak bazaltik lav akıntıları ile örtülerek günümüze kadar muhafaza edilmişlerdir. Belki de dünyanın muhtelif sahalarında benzer şekilde Erken Pleistosen dönemi taraçaları oluşmuş olabilir, ancak bu taraçalar oluşumlarını müteakip eden dönemlerde (Kula yöresinde oluşanların aksine) herhangi bir örtü ile korunamadıklarından erozyona uğramışlar ve günümüze kadar varlılarını muhafaza edememişlerdir.

Kula yöresi Erken Pleistosen taraçaları küresel iklim değişiminin kanıtları olmalarının yanında paleo-ortam koşulları ile ilişkili verileri de barındırmaları nedeniyle oldukça önemli bir arşiv niteliği de taşımaktadırlar. Bu özellikleri ile Erken Pleistosen taraçaları tüm insanlığın 
ortak mirası niteliğinde sitler olup uluslararası öneme sahiptirler. Söz konusu taraçalar ve bunların oluşumunu konu alan çok sayıda uluslararası yayının yapılmış olması bu durumun en açık göstergesidir.

\section{Batı Anadolu'da Kula Volkanik Yöresinde İnsana Ait En Eski Paleolitik Artefact}

Asya, Avrupa ve Afrika kıtalarının birbirlerine en fazla yaklaştığı bir konumda bulunması ve bu bakımdan önemli bir köprü özelliğinde olması bakımından Anadolu, insanlık tarihi açısından önemli bir coğrafyadır. Değişik disiplinler kapsamında yapılan bilimsel çalışmalar Anadolu coğrafyasının Erken Pleistosen insanları için önemli bir göç güzergâhı ve yerleşme alanlarından birini oluşturduğu gerçeğini ortaya koymuştur. Ancak bu çalışmalar kapsamında elde edilen kayıtlar ya güvenilir yaş tayinleri ile teyit edilememiş veya yayınlanmış yaş tayinleri arasında önemli birtakım farklılıklar bulunmaktadır.

Türkiye'de insana ait en eski izler Büyük Menderes vadisinde, Denizli'nin Kocabaş mevkiinde tespit edilmiştir. Burada traverten depoları içerisinde Homo Erectus insanına ait kafatası kalıntıları tespit edilmiştir (Kappelman et al. 2008). Başlangıçta Termo luminescence yaş belirleme metodu kullanılarak bu kafatası parçalarının yaşının 490-510 bin yılları arasında olduğu belirlenmiştir (Kappelman et al. 2008). Ancak, sonradan magnetic polarite ölçümleri ve cosmogenic isotop gömülme yaşı metodları kullanılarak bu kafatası parçalarının alt ve üst kısmını oluşturan sedimanların yaşlarının tespiti ile söz konusu fosilin yaşının1.1-1.3 milyon yılları arasında olduğu önerilmiştir (Lebatard et al. 2014). Türkiye'nin diğer bölgelerinde de insana ait deliller büyük bir çoğunlukla Alt Paleolitik'e ait olduğu ileri sürülen taş aletler şeklindeki bulgular ile sınılıdır (Harmankaya \& Tanındı 1996). Bütün bunlar Anadolu'da ilk insanların yaşayış ve dağılım kronolojisi için gerekli olan stratigrafik veya jeokronolojik delillerin henüz güvenilir derecede ortaya konulmadığına işaret etmektedir (Kuhn 2002, 2010).

Kula volkanik yöresinde, Burgaz Platosu'nun güney kesiminde Paleo-Gediz tarafından oluşturulmuş bir menderes büklümüne ait taşkın ovası sedimanları içerisinde Paleolitik döneme ait ve kuvarsitten oluşan insan el ürünü bir artefakt (sert çekiç) bulunmuştur. Gediz Nehri tarafindan oluşturulmuş bu paleo-menderes, Burgaz Platosu'nun güneyinde, platonun batı ve doğu kollarını oluşturan lav akıntıları arasındaki gully şekli gösteren bir vadide ve Miyosen havzası dolgularından oluşan düz bir yüzey üzerinde uzanır.

Gediz Nehri, Erken Pleistosen döneminde (yaklaşık olarak 1.24 milyon yıl önce), Burgaz Platosu'nun güneyinde bulunan Kale Tepe mevkiindeki yatağında akmakta iken, Burgaz Platosu'nun kuzeyinde bulunan Bağtepe volkanının faaliyete geçmesi sonucunda lav akıntıları ile bloke olmuştur. Bunun sonucunda, nehir önce kuzeye, sonra güney ve daha sonra ise batıya yönelerek kendisine yay şeklinde (menderes) yeni bir yatak oluşturmuştur (Fig. 6). Gediz, yaklaşık olarak 70 bin yıl süresince bu menderesli yatağında aktıktan sonra, Burgaz-Bağtepe volkanının yeniden faaliyete geçmesi sonucunda aşağı çı̆̆ırda ve güneybatıda, Sarnıç Platosunun güney kesiminde, bir kez daha bloke olmuş ve oluşan lav setinin gerisinde volkanik bir lav seti gölü meydana gelmiştir. İşte söz konusu artefakt bu göl içerisinde biriken gölsel sedimanlar ile bunların hemen altında bulunan taşkın ovası depolarının dokanak noktasında ve güncel Gediz yatağından yaklaşık olarak $143 \mathrm{~m}$ yukarıda tespit edilmiştir. Bu lokasyon bugün için Kale Tepe’nin hemen kuzeyinde guly özelliği gösteren bir vadi içerisinde bulunmaktadır. Artefaktın içerisinde bulunduğu flüviyal deponun (taraça) yaşı, bu depo ile ilişkili olan volkanik lav akıntılarının Ar-Ar radyometrik yaş tayini ile belirlenmiştir (Fig. 7). Bulgular, söz konusu artefaktın yaşının günümüzden 1.24 - 1.70 milyon yılları arasındaki döneme ait olduğunu ve insanların bu dönemde Anadolu'da yaşadıklarına veya bu dönemde Anadolu'dan Avrupa'ya göç ettiklerine işaret etmektedir.

$\mathrm{Bu}$ artefakt, Anadolu'da bulunmuş ve güvenilir bir şekilde yaşlandırılmış en eski insan el ürünü olup, ulusal-uluslararası düzeyde öneme sahip arkeolojik bir bulgudur. Söz konusu artefakt, 
insanlık tarihi açısından son derece önemli bir kanıt durumundadır. Artefaktın içinde bulunduğu Erken Pleistosen Paleo-Gediz sedimanları bu özellikleri ile bölgenin jeo-arkeolojik geçmişi açısından oldukça büyük bir öneme sahiptir. Söz konusu artefaktın bulunduğu lokalitenin jeosit olarak belirlenip koruma altına alınması oldukça önemlidir. Çünkü bu saha, hem Batı Anadolu'nun insanlık tarihi ve hem de küresel anlamda tüm insanlık tarihine ilişkin buluntuları barındıran dünyanın nadide alanlarından birini oluşturmaktadır.

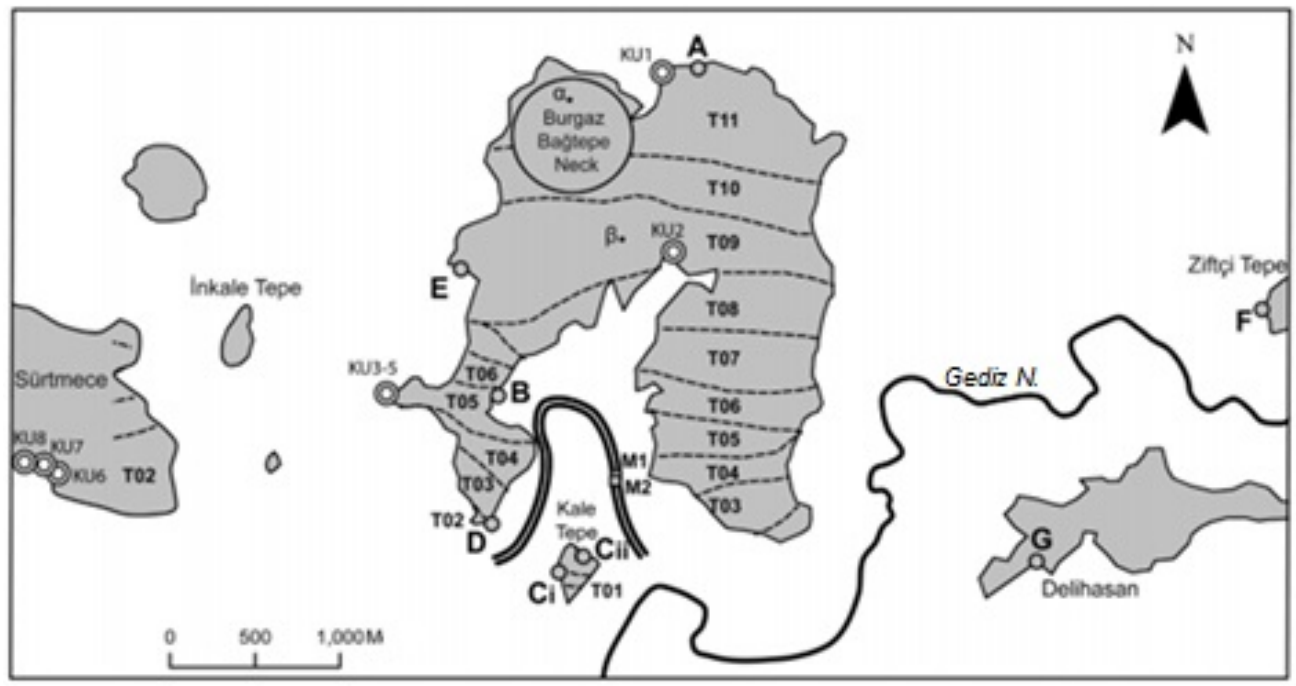

Fig. 6. Burgaz Platosu ve Gediz'in Erken Pleistosen volkanizması sonucu bloke edilmesi sonrasında oluşan gömülmüş paleo-menderesin rotası

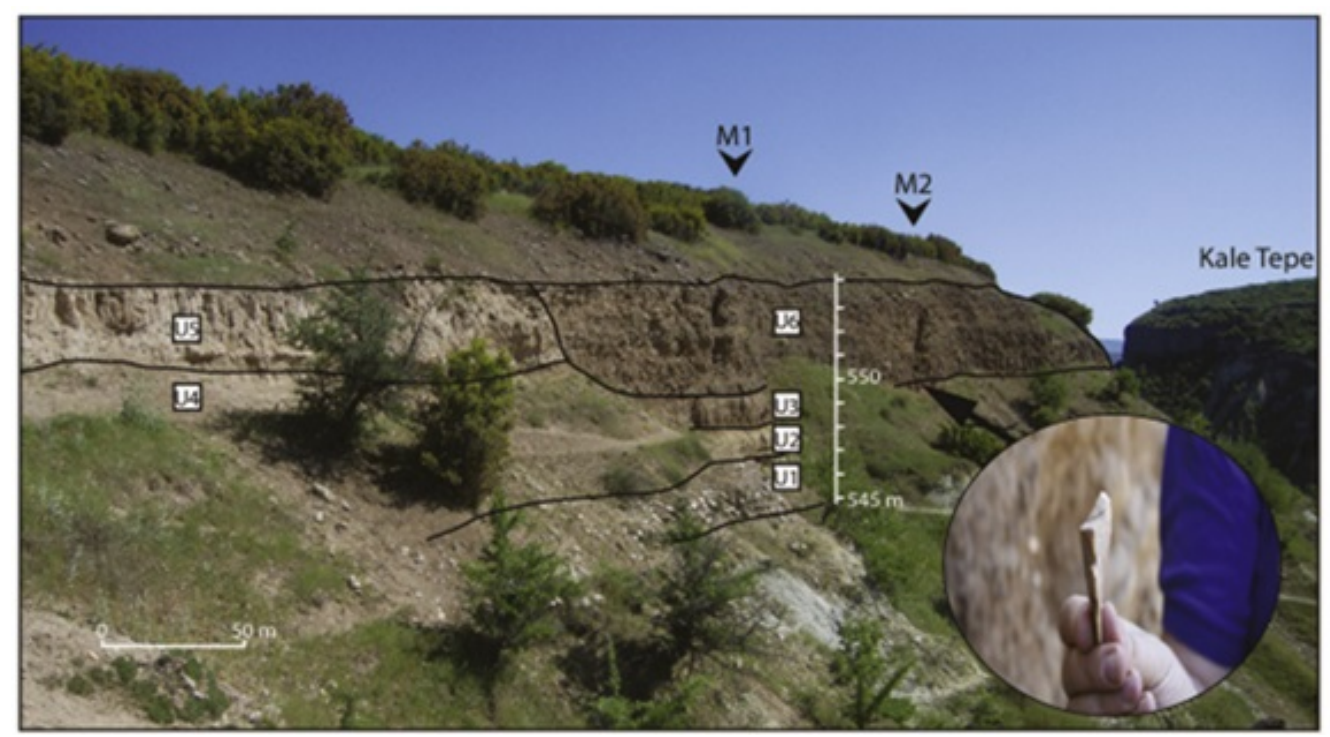

Fig. 7. Burgaz Platosu'nun güney kesiminde paleo-menderes vadisinin doğu yamacinda içerisinde artefaktın tespit edildiği sedimanter depolardan bir görünüm (U1: Miyosen havza dolguları üzerinde Paleo-Gediz çakılları, U2 ve U3: Taşkın ovası depolarını oluşturan alüviyal kum ve siltler, U4 ve U5: Kireçli-gölsel depolar)

\section{Geç Holosen Katastrofik Seli ve Sel Blokları}

Flüviyal süreçler ve bu süreçlerle ilgili akarsu sedimanları yeryüzünün herhangi bir sahasında geçmiş dönemlerde etkili olmuş süreçler ve dolayısı ile paleo-ortam koşulları (Örneğin; iklim salınımları veya tektonik olayların tür ve hızında meydana gelen değişmeler v.b.) ile ilgili kayıtları muhafaza eden en önemli doğal arşiv alanlarıdır. Özellikle son 50 yılda bilim insanları 
dünyanın değişik yerlerinde nehir depoları ve bu arada akarsu taraçaları üzerine yapmış oldukları araştırmaları sonucunda Kuvaterner süresince global ölçekte meydana gelen iklim değişimleri ve yeryüzünün değişik yörelerinde meydana gelmiş tektonik hareketlerin özellikleri hakkında önemli bulgulara erişmişlerdir. Nitekim, bu türde bilimsel araştırmaları önemseyen UNESCO, IGCP-449 (Global correlation of Late Cenozoic fluvial deposits) ve IGCP-518 (Fluvial sequences as evidence for landscape and climatic evolution in the Late Cenozoic) gibi desteklediği projelerle dünyanın muhtelif yerlerinde Kuvaterner jeomorfolojisi üzerine araştırmalar yapan yerbilimcileri değişik ülkelerde organize ettiği konferanslar yoluyla bir araya getirerek yapılan çalışmaların sonuçlarının tartışılması, korelasyon ve koordinasyonunu sağlayarak, Kuvaterner süresince etkili olan süreçlerin global ölçekte resminin ortaya konulmasına yardımcı olmuştur.

Yukarda belirtilen projeler kapsamında van Gorp et al. 2013, Kula yöresinde Geç Holosen dönemi volkanizmasının flüviyal süreçler üzerine etkisini sistematik bir şekilde incelemiştir. Şöyle ki; yörede Kula Divlit volkanı faaliyeti öncesinde, bugünkü Kula Şehri'nin de içerisinde bulunduğu sahanın sularını drene eden bir akarsu (Kula Çayı), Kula'nın yaklaşık olarak 20 km kuzeyinde ve bugünkü Hoca Seyfettin Köprüsü'nün hemen yakınında Gediz nehri ile birleşmekte idi. Yaklaşık olarak 2.6 - 3 binyıl öncesinde Kula şehrinin hemen doğusunda bulunan Divlit volkanının faaliyete geçmesi neticesinde çıkan lavlar, Kula çayı vadisini takip ederek, önce Hoca Seyfettin Köprüsü yakınında ve daha aşağı çığırda da Gediz-Geren kolunun kavuşum noktasında olmak üzere Gediz'i iki lokasyonda bloke etmişlerdir (Fig. 8).

Aşağı kesimde oluşan lav seti, hem Gediz nehrini ve hem de onun kolunu oluşturan Geren Çayı'nı 1,5 km yukarı çığırına kadar bloke etmiştir. Böylece biri yukarı çığırda ve diğeri de hemen onun aşağ 1 kesiminde olmak üzere 2 adet volkanik set gölü meydana gelmiştir (Fig. 8). Yukarı çı̆̆ırda oluşan volkanik set gölü Gediz tarafından taşınan bütün sedimanı tutarak yoğun siltasyon oluştururken, bütün sediman birinci gölde tutulduğu için, bunun yaklaşı olarak 1.5 $\mathrm{km}$ aşağısında oluşan 2. gölde ise siltasyon oldukça sınırlı ölçülerde kalmıştır. Bu 2. gölün suları aynı zamanda Gediz'in kolunu oluşturan ve sahadaki badlands topografyasının gelişimi için taban seviyesi rolü gören Geren vadisinin aşağı mecrasını da işgal etmiştir. Bu göllerin bir süre varlığını devam ettirmesini müteakip, 2. gölde biriken sular zamanla göl oluşumuna sebep olan lav seti üzerinden taşarak setin hemen aşağ kesiminde Gediz vadisini derinleștirmiş ve lav setini alttan oyarak onun yıkılmasına sebep olmuştur. Bu gölün ortadan kalkmasının ardından taban seviyesi alçalmış ve oluşan bu yeni taban seviyesine bağlı olarak Gediz nehri yatağında bir geriye aşınım dalgası gelişmiştir. Bu aşınım dalgası zamanla yukarı gölü oluşturan lav setini de alttan oyarak onun katastrofik bir șekilde yıkılmasına sebep olmuştur (Fig. 8). Böylece, birinci gölü olușturan lav setinin gerisinde serbest hale geçen göl suları hızla akıșa geçerek hem Gediz yatağında ve hem de yakın civarda, boyutları $10 \mathrm{~m}^{3}$ ü bulan konglomera ve travertenlerden oluşan büyük kaya bloklarını da beraberinde sürükleyerek hızla yatağına gömülmüş ve bir boğaz (epigenetic gorge) olușturmuștur. Bugün söz konusu alanda gölü olușturan seddin parçalanmasından ortaya çıkan devasa blokların suyun akış yönünde dizilim gösterdiği (devasa blokların imbrikasyonu veya yönelimle) görülür. Blokların boyutu ve imbrikasyonu gerçekleşen katastrofik olayın boyutlarını göstermektedir (Fig. 9). Öte yandan yukarı gölü oluşturan suların hızla boşalması ve nehrin daha önce birikmiş olan göl sedimanlarının içerisine hızla gömülmesi, aynı zamanda bölgede erozyon ve kütle hareketlerini de tetiklemiştir. 


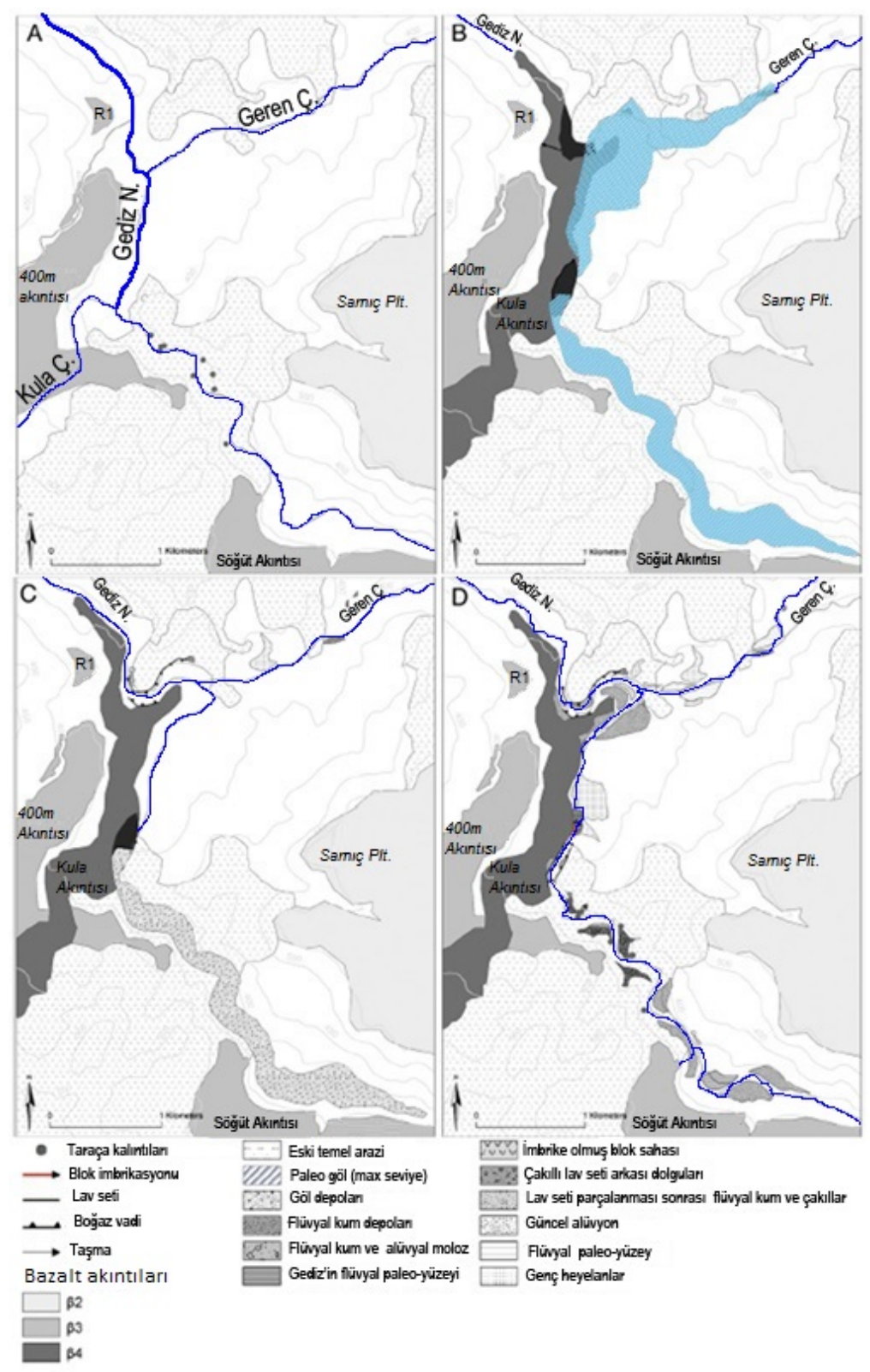

Fig. 8. Gediz Nehri ve Geren Çayı üzerinde Holosen Dönemi volkanik lav setleri ve bunlarla ilgili göl oluşumları (van Gorp et al. 2013). (A) Volkanizma öncesi durum, (B) Divlit konisinden kaynağını alan bazaltik lavların Kula Çayını takip ederek güneyde Gediz Nehri'ne akması ve Gediz'i iki lokasyonda bloke etmesi, (C) Aşağı çı̆̆ırda lav settinin parçalanması ve bununla ilgili boğaz oluşumu, (D) Yukarı çı̆̆ırdaki lav setinin katastrofik şekilde parçalanması, bununla ilgili heyelanlar, büyük kaya bloklarının imbrike olması ve taraça oluşumu)

Yukarıdaki açıklamalardan anlaşılacağı gibi aynı lav akıntısı bir nehrin farklı noktalarında birden fazla lav seti oluşturabilir. Bu lav setleri akarsuyun boyuna profilinin eğiminde lokal olarak birden fazla eğim kırıklıkları oluşturabildiği gibi, lav setlerinin yukarı ve aşağı çı̆̆ırlarında etkili olan flüviyal sistemlerinin de bütünü ile birbirlerinden farklı olması sonucunu doğurabilir. Oluşan lav setleri öncelikle lokal taban seviyesi yükselmesine sebep olur. Bu durum lav setinin ön ve arka çığırındaki havza bölümlerinde flüviyal sistemlerin işleyişinde aşınım ve birikim bakımından önemli farkl11ıklar oluşturabilir. Şöyle ki; Lav setinin gerisinde göl oluşumu ve siltasyon, lokal olarak yerel taban seviyesi yükselmesini oluşturur. Akarsuyun göle birleştiği ağız 
kısmında ise delta gelişir ve bu delta zamanla aşağı kesime doğru büyür. Azalan yatak eğimine bağlı olarak da akarsuyun menderesli bir akış göstermesi, göl suları vadi yamaçlarını oluşturan birimler içerisine sızma yaparak yamaç stabilitesinin azalmasına ve dolayısı ile kütle hareketlerine sebep olabilir. Nitekim Geren Çayı'nın aşağı kesiminde oluşan göl kıyısında hem delta oluşmuş hem de göl kıyılarında artan satürasyon olayına bağlı olarak yamaç stabilitesi azalmış ve bu da bazı kütle hareketlerini tetiklemiştir. Gölün bütünü ile dolması sonucunda taşan ve sediman bakımından oldukça fakir olan sular, lav setinin aşağı kesiminde akarsu yatağında derine aşındırma yaparak, taban seviyesini negatif yönde alçaltır ve bu durum da vadinin boyuna profilinde önemli eğim kırıklığı oluşturur. Oluşan bu eğim kırıklığını ortadan kaldırmak amacı ile akarsu yatağında bir geriye aşınım dalgası başlatır ve bu aşınım zamanla lav setini de alttan oyarak onu ortadan kaldırabilir. Lav setinin özellikle katastrofik olarak ortadan kalkması durumunda (oluşan yeni taban seviyesine uygun olarak) akarsu hızla lav setinin gerisindeki gölsel sedimanlar içerisine gömülerek onları ortadan kaldırabildiği gibi, aynı geriye aşınım hem ana akarsu vadisini ve hem de onun kollarını da takip ederek zamanla bütün havzayı kapsayarak erozyonal süreçlerde bir hızlanma şeklinde etkili olur.

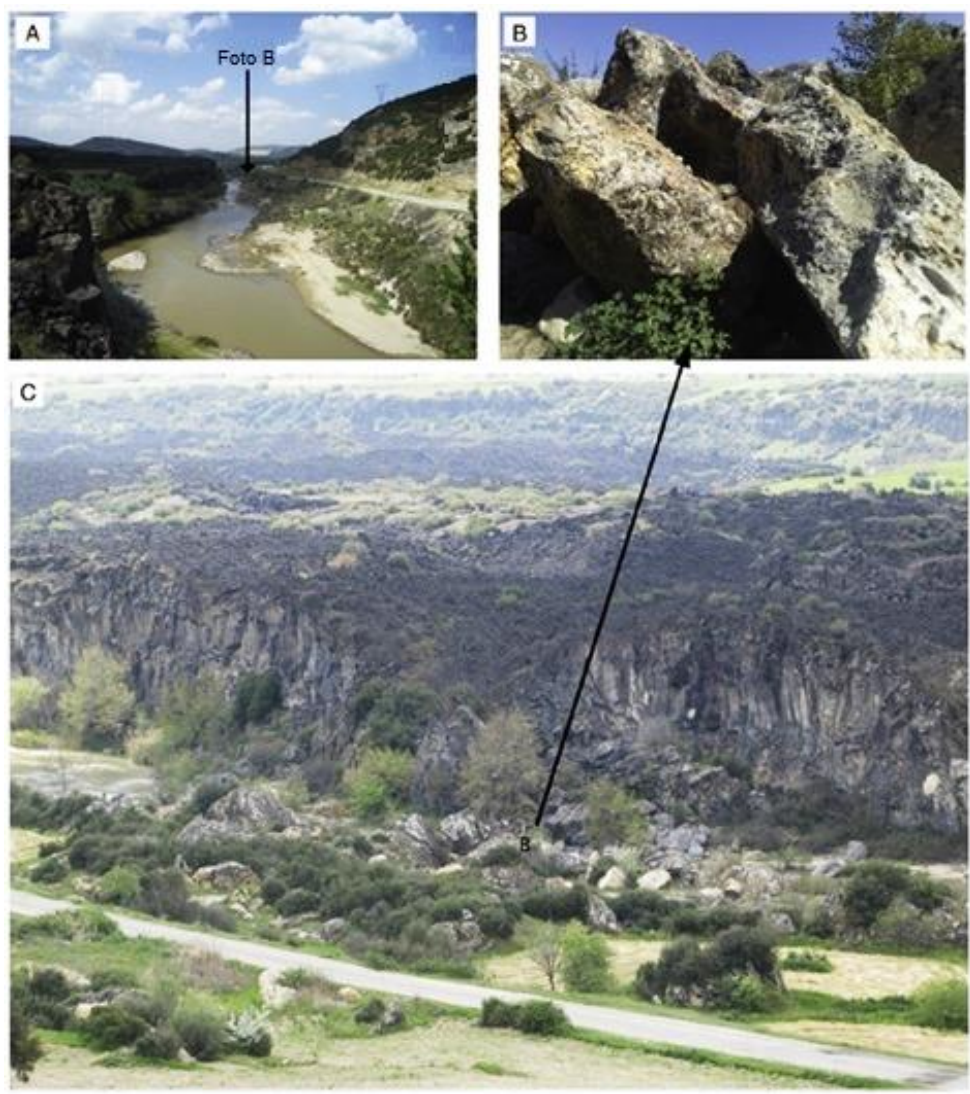

Fig. 9. (A) Hoca Seyfettin Köprüsünden Gediz Nehrinin oluşturduğu boğazdan bir görünüm, (B) ve (C) Gediz yatağı içerisinde yukarı çığırda (Hoca Seyfettin Köprüsü yakınında) lav seti gölünün katastrofik bir şeklide ortadan kalkması sonucu oluşan sellenmeden dolayı taşınan konglomera ve traverten bloklarının akış yönünde imbrikasyonu (van Gorp et al. 2013)

Geç Holosen'de gerçekleşen ve o dönem insanının bizzat şahit olduğu bu katastrofik olay yerbilimleri ve insanlık tarihi açısından kanaatimizce uluslararası öneme sahiptir. Nitekim UNESCO Global Jeoparklar Ağının faaliyet alanları içerisinde Doğal Afetler ve Risklerin Azaltılması Alt Çalışma Grubu (Geohazard Risc Reduction Group) mevcuttur. Söz konusu grubun varlığ Global Jeoparklar Ağı'nın sözkonusu güncel ve geçmiş dönem doğal afetlerine atfettiği önemin en açık göstergesidir. 


\section{Sonuç}

Kula Jeoparkı Türkiye'nin ve Türk Cumhuriyetlerinin ilk ve tek UNESCO tescilli jeoparkıdır. Jeopark alanı ve yakın çevresinde volkanizma Neojen'de (Orta Miyosen) başlamış ve aşamalı olarak Holosen'e kadar devam etmiştir. Alan sahip olduğu volkanik şekiller nedeniyle birçok seyyah ve bilim insanının dikkatini çekmiş ve yine bu özelliğine binaen Global Jeopark unvanını kazanmıştır. Bu nedenle alanı doğrudan veya dolaylı ilgilendiren çok sayıda uluslararası yayın yapılmıştır.

$\mathrm{Bu}$ araştırmada Kula UNESCO Global Jeoparkı içerisinde yer alan uluslararası öneme sahip 3 yeni potansiyel jeosit önerilmiştir. Önerilen jeositler, küresel iklim değişikliği, Paleo-coğrafya, Paleo-ekoloji ve geçmişte yaşanan doğal afetler hakkında oldukça önemli bilgiler barındırmakta ve bu nedenle yer ve insanlık tarihinin önemli kanıtları olma özelliğini taşımaktadırlar.

Söz konusu sitlerin uluslararası öneme sahip jeosit olarak belirlenip Global Jeoparklar ağına bildirilmesi, bu alanların, eğitsel, bilimsel, turistik açıdan korunup gelecek kuşaklara aktarılması açısından büyük önem taşımaktadır.

Bu sitlerin korunup tanıtılması, Kula yöresinin sosyo-ekonomik kültürel kalkınmasına, yörenin turistik öneminin ve marka değerinin artmasına ve ülke genelinde bilimin popülerleşmesine önemli katkılar sunacaktır.

\section{KAYNAKÇA}

Aksu A. E., Piper D. J. W. \& Konak T. (1987). "Quaternary Growth Patterns of the Büyük Menderes and Küçük Mederes Deltas, Western Turkey”. Marine Geology 76 (1987) 89-104.

Bozkurt E. \& Sözbilir H. (2004). "Tectonic Evolution of the Gediz Graben: Field Evidence for an Episodic Two-Stage Extension in Western Turkey”. Geological Magazine 141 (2004) 63-79.

Bozkurt E. (2001). "Neotectonics of Turkey a Synthesis”. Geodin Acta 14 (2001) 3-30.

Bunbury J. M., Hall L., Anderson G. J. \& Stannard A. (2001). "The Determination of Fault Movement History from the Interaction of Local Drainage with Volcanic Episodes”. Geol. Mag. 138 (2001) 185192.

Ercan E., Türkecan A., Dinçel A. \& Günay E. (1983). “Kula-Selendi (Manisa) Jeolojisi”. Jeoloji Mühendisligi 17 (1983) 3-28

Ercan T. \& Öztunalı Ö. (1982). "Characteristic Features and "Base Surge" Bed Forms of the Kula Volcanics”. Bull. Geol. Soc. Turkey 25 (1982) 117-125.

Ercan T. (1993). "Interpretation of Geochemical, Radiometric and Isotopic Data on Kula Volcanics (Manisa-Western Anatolia)”. Geol. Bull. Turk. 36/1 (1993) 113-129.

Erinç S. (1970). "Kula Adala Arasında Genç Volkanik Topografya". İstanbul Universitesi Cografya Enstitüsü Dergisi 17 (1970) 7-22.

Ersoy E. \& Helvac1 C. (2007). "Stratigraphy and Geochemical Features of the Early Miocene Bimodal (Ultrapotassic and Calc-Alkaline) Volcanic Activity Within the NE-Trending Selendi Basin, Western Anatolia, Turkey”. Turkish Journal of Earth Science 16 (2007) 117-139.

Ersoy Y., Helvac1 C. \& Sozbilir H. (2010). "Tectono-Stratigraphic Evolution of the $€$ NE SW-Trending Superimposed Selendi Basin: Implications for Late Cenozoic Crustal Extension in Western Anatolia, Turkey”. Tectonophysics 488 (2010) 210-232.

Hamilton W. J. \& Strickland H. E. (1841). “On the geology of the western part of Asia Minor”. Trans. Geol. Soc. Lond. 6 (1841) 1-39.

İnci U. (2002). "Depositional evolution of Miocene coal successions in the Soma coal field., Western Turkey”. International Journal of Coal Geology 51 (2002) 1-29.

Kayan İ. (1992). "Demirköprü baraj gölü batı kıyısında Çakallar volkanizması ve fosil insan ayak izleri (The Çakallar volcanism and human footprints on the bottom of pyroclastic layers. Western Anatolia) (32 sayfa, 3 fotoğraf, 5 şekil, Türkçe metin, İngilizce özet)”. Ege Coğrafya Dergisi 6 (1992) 1-32.

Kroon D., Alexander I., Little M., Lourens L. J., Matthewson A., Robertson A. H. F. \& Sakamoto T. (1998). "Oxygen Isotope and Sapropel Stratigraphy in the Eastern Mediterranean During the Last Million Years”. Proceedings of the Ocean Drilling Program, Scientific Results 160 (1998) 181-189.

Maddy D. (1997). "Uplift-Driven Valley Incision and River Terrace Formation in Southern England”. 
Journal of Quaternary Science 12 (1997) 539-545.

Maddy D., Demir T., Bridgland D., Veldkamp A., Stemerdink C., van der Schriek T. \& Westaway R. (2005). “An Obliquity-Controlled Early Pleistocene River Terrace Record from Western Turkey?”. Quaternary Research 63 (2005) 339-346.

Maddy D., Demir T., Bridgland D., Veldkamp A., Stemerdink C., van der Schriek T. \& Schreve D. (2007). "The Pliocene Initiation and Early Pleistocene Volcanic Disruption of the Palaeo-Gediz Fluvial System, Western Turkey”. Quaternary Science Reviews 26 (2007) 2864-2882.

Maddy D., Demir T., Bridgland D., Veldkamp A., Stemerdink C., van der Schriek T. \& Westaway R. (2008). "Theearly Pleistocene Development of the Gediz River, Western Turkey: An Uplift-Driven, Climate-Controlled System?”. Quaternary International 189 (2008) 115-128.

Maddy D., Demir T., Veldkamp A., Bridgland D. R., Stemerdink C., van der Schriek T. \& Schreve D. (2012). "The Obliquity-Controlled Early Pleistocene Terrace Sequence of the Gediz River, Western Turkey: A Revised Correlation and Chronology”. J. Geol. Soc. Lond. 169 (2012) 67-82.

Maddy D., Schreve D., Demir T., Veldkamp A., Wijbrans J. R., van Gorp W., van Hinsbergen D. J. J., Dekkers M. J., Scaife R., Schoorl J. M., Stemerdink C. \& van der Schriek T. (2015). “The Earliest Securely-Dated Hominin Artefact in Anatolia?”. Quat. Sci. Rev. 109 (2015) 68-75.

Maddy D., Veldkamp T., Demir T., van Gorp W., Wijbrans J. R., Hinsbergen D. J. J., Dekkers M. J. Schreve D., Schoorl J. M., Scaife R., Stemerdink C., van der Schriek T., Bridgland D. R. \& Aytaç A. S. (2017). "The Gediz River Fluvial Archive a Benchmark for Quaternary Research in Western Anatolia”. Quaternary Sclence Reviews 157 (2017) 1-18.

Ozaner F. S. (1992). "Detecting the Polycyclic Drainage Evolution in Kula Region (western Turkey) Using Aerial Photographs”. ITC J. 1992-3 (1992) 249-253.

Philippson A. (1913). “Das Vulkangebietvon Kula in Lydien, die Katakekaumane der Alten”. Pet. Geogr. Mitt. 2 (1913) 237-241.

Purvis M. \& Robertson A. H. F (2004). “A Pulsed Extension Model for the Neogene-Recent E-W Trending Alaşehir Graben and the NE-SW Trending Selendi and Gördes Basins, Western Turkey”. Tectonophysics 391 (2004) 171-201.

Richardson-Bunbury J. M. (1992). The Basalts of Kula and the Irrelation to Extension in Western Turkey. PhD Thesis. Cambridge University, Cambridge 1992.

Richardson-Bunbury J. M. (1996). “The Kula Volcanic Field, Western Turkey: The Development of a Holocene Alkali Basalt Province and the Adjacent Normal-Faulting Graben”. Geological Magazine 133 (1996) 275-83.

Sarica N. (2000). “The Plio-Pleistocene Age of the Büyük Menderes and Gediz Grabens and Their Tectonic Significance on N-S Extensional Tectonics in West Anatolia: Mammalian Evidence from the Continental Deposits”. Geological Journal 35 (2000) 1-24.

Seyitoğlu G. (1997). "Late Cenozoictectono-Sedimentary Development of the Selendi and Uşak-Güre Basins: a Contribution to the Discussion on the Development of East-West and North Trending Basins in Western Turkey”. Journal of the Geological Society of London 134 (1997) 163-175.

van Gorp W., Veldkamp A., Temme A. J. A. M., Maddy D., Demir T., van der Schriek T., Reimann T., Wallinga J., Wijbrans J. \& Schoorl J. M. (2013). "Fluvial Response to Holocene Volcanic Damming and Breaching in the Gediz and Geren Rivers, Western Turkey”. Geomorphology 201 (2013) 430448. doi:10.1016/j.geomorph.2013.07.016.

Veldkamp A., Candy I., Jongmans A. G., Maddy D., Demir T., Schoorl J. M., Schreve D., Stemerdink C. \& van der Schriek T. (2015). "Reconstructing Early Pleistocene (1.3 Ma) Terrestrial Environmental Change in Western Anatolia: Did it Drive Fluvial Terrace Formation?”. Palaeogeogr. Palaeoclimatol. Palaeoecol. 417 (2015) 91-104.

Washington H. S. (1894). “On the Basalts of Kula”. Am. J. Sci. 47 (1894) 114.

Washington H. S. (1900). “Thecomposition of Kulaite”. J. Geol. 8 (1900) 610-620.

Westaway R., Pringle M., Yurtmen S., Demir T., Bridgland D. R., Rowbottom G. \& Maddy D. (2004). Pliocene and Quaternary Regional Uplift in Western Turkey: The Gediz River Terrace Staircase and the Volcanism at Kula”. Tectonophysics 391 (2004) 121-169.

Westaway R., Pringle M., Yurtmen S., Demir T., Bridgland D., Rowbotham G. \& Maddy D. (2003). "Pliocene and Quaternary Surface Uplift of Western Turkey Revealed by Long-Term River Terrace Sequences”. Current Science 84 (2003) 1090-1101. 